
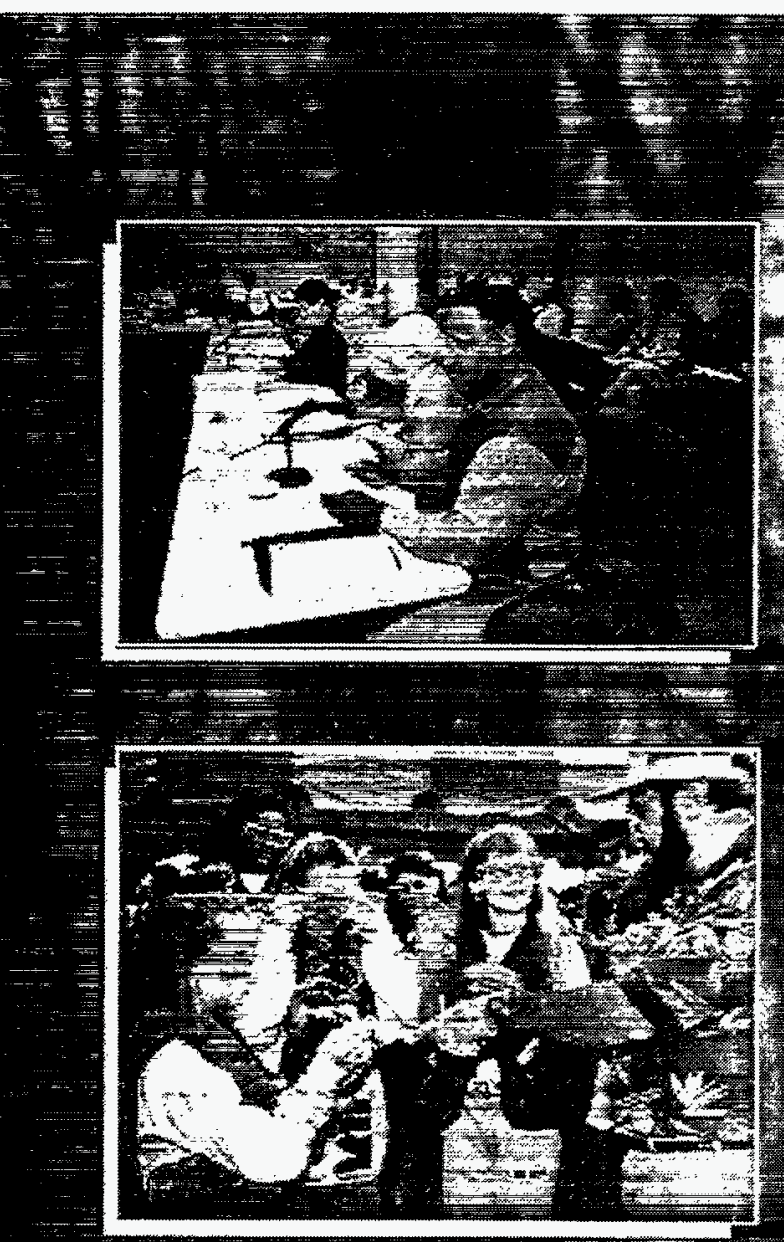

\title{
(x)
}

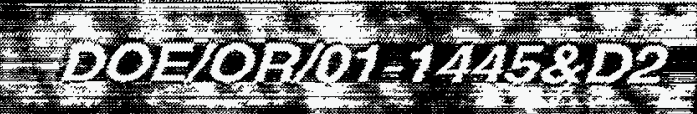

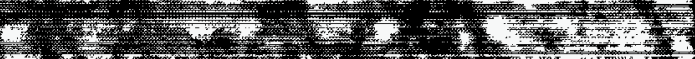

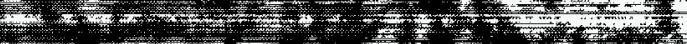

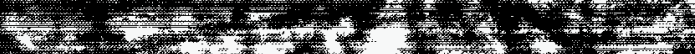

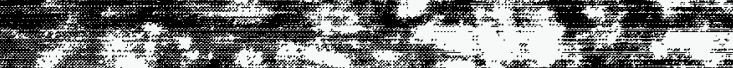

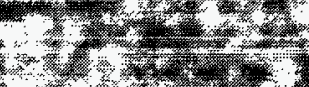

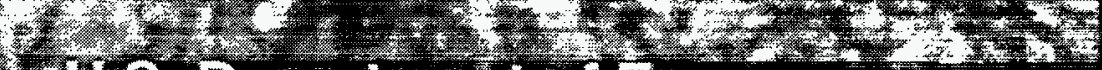
T1S. Department of Energy

Tak Bidge Operations Enyronmental Management $\frac{1}{21}$

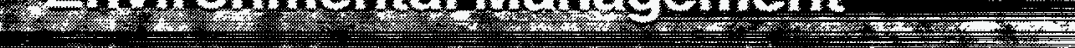

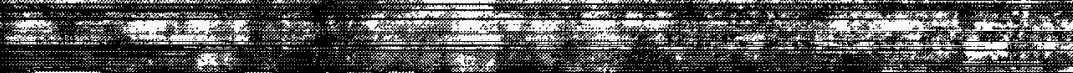
Ruble
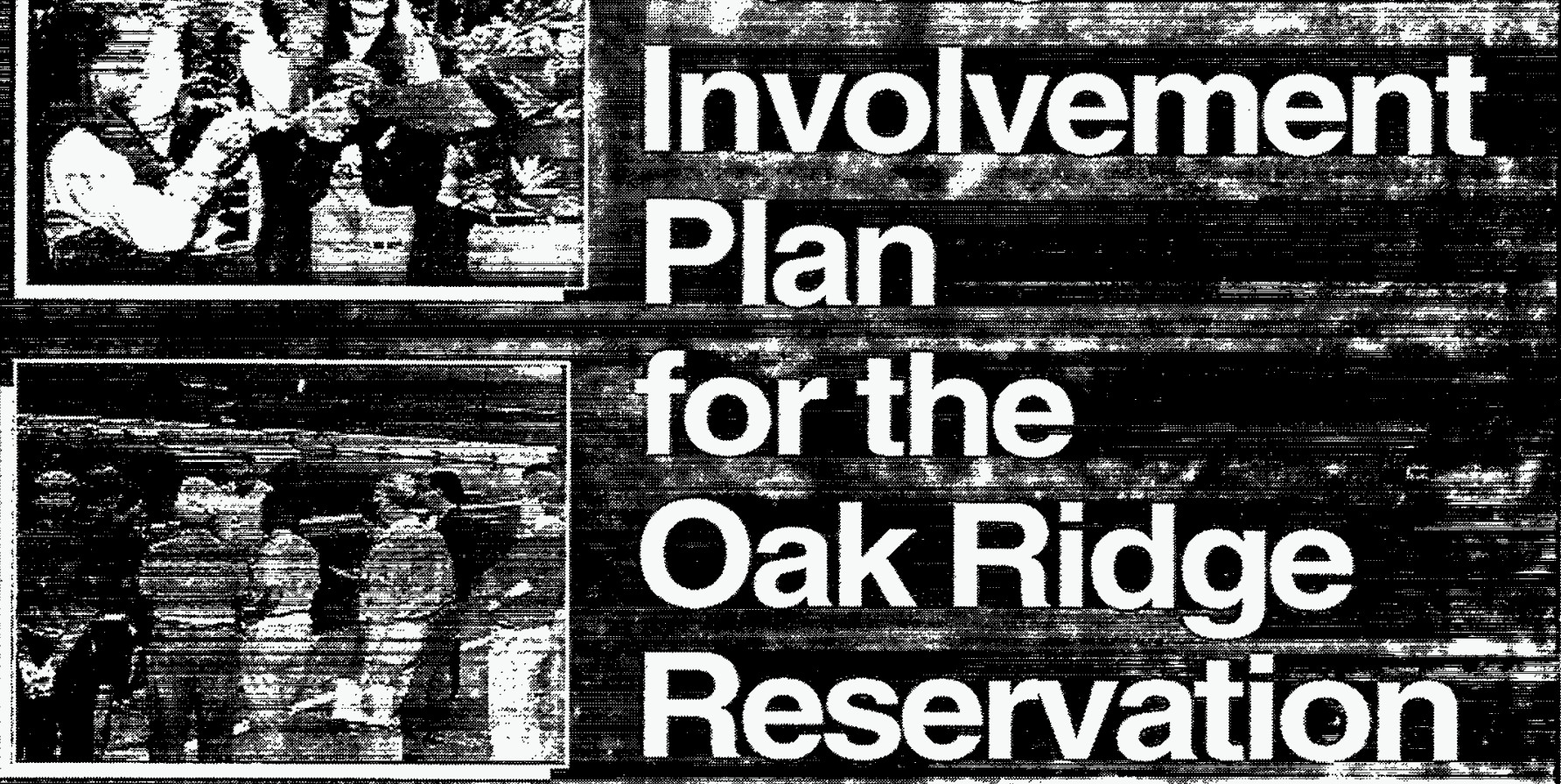

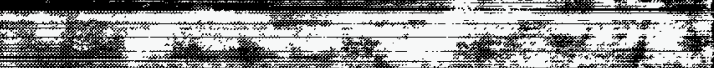

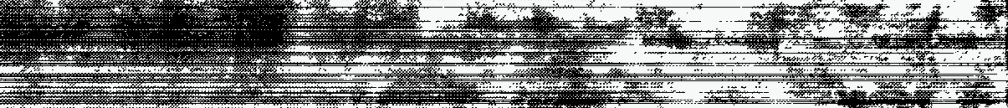

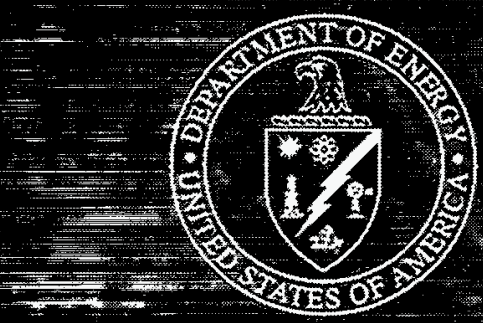

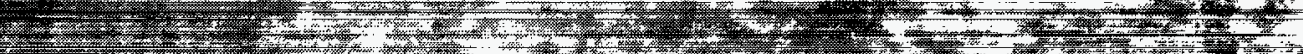

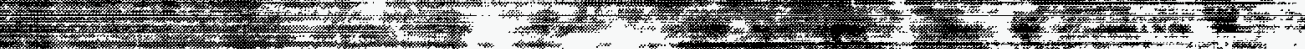
(1)

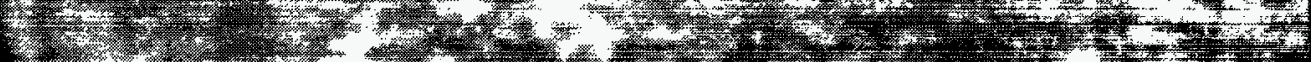

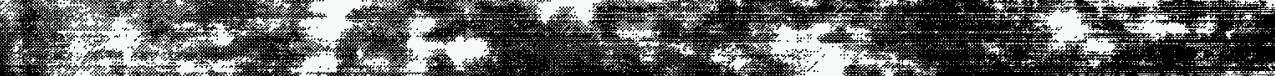

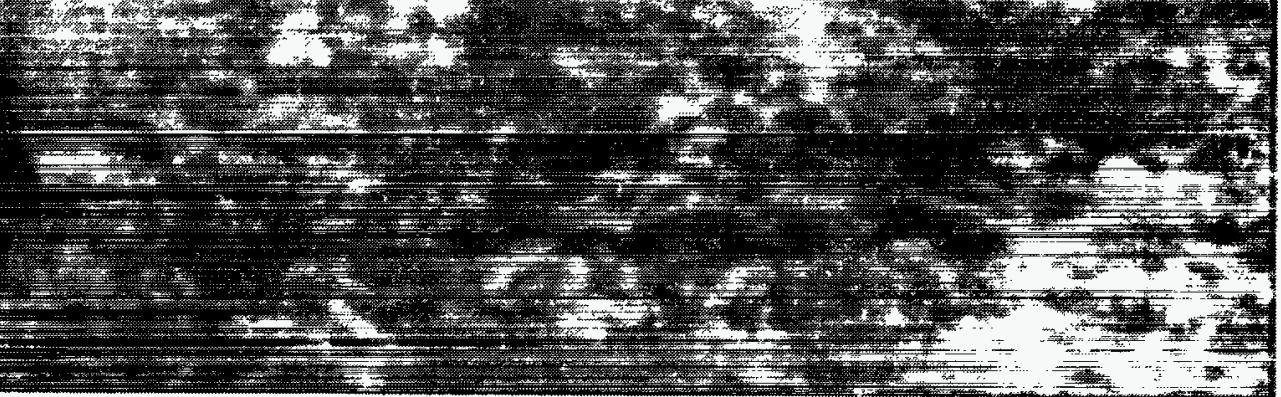


This document supersedes the Environmental Restoration Community
Relations Plan for the Oak Ridge Reservation (DOE/ORO-928)
published in March 1991; the Public Involvement Plan for the Oak
Ridge Reservation (DOE/ORO-928, Rev. 1) published in March 1995;
and the Public Involvement Plan for the Oak Ridge Reservation
(DOE/ORO-928, Rev. 2) published in September 1995. 
Energy Systems Environmental Restoration Program

\section{U.S. Department of Energy \\ Oak Ridge Operations \\ Environmental Management \\ Public Involvement Plan \\ for the Oak Ridge Reservation}

Date Issued—June 1996

Prepared by

Science Applications International Corporation

Oak Ridge, Tennessee

under subcontract 43B-99069C, Y-05

LOCKHEED MARTIN ENERGY SYSTEMS, INC.

managing the

Environmental Management Activities at the

Oak Ridge K-25 Site Paducah Gaseous Diffusion Plant

Oak Ridge Y-12 Plant Portsmouth Gaseous Diffusion Plant

Oak Ridge National Laboratory

under contract DE-AC05-84OR21400

for the

U.S. DEPARTMENT OF ENERGY

This document has been approved by the K-25 Site Technical Information Office for release to the public. Date: $6 / 11 / 96$ 
This report has been reproduced directly from the best available copy.

Available to DOE and DOE contractors from the Office of Scientific and Technical Information, P.O. Box 62, Oak Ridge, TN 37831; prices available from 423-576-8401 (fax 423-576-2865).

Available to the public from the National Technical Information Service, U.S. Department of Commerce, 5285 Port Royal Rd., Springfield, VA 22161.

\section{Science Applications International Corporation}

contributed to the preparation of this document and should not be considered an eligible contractor for its review. 


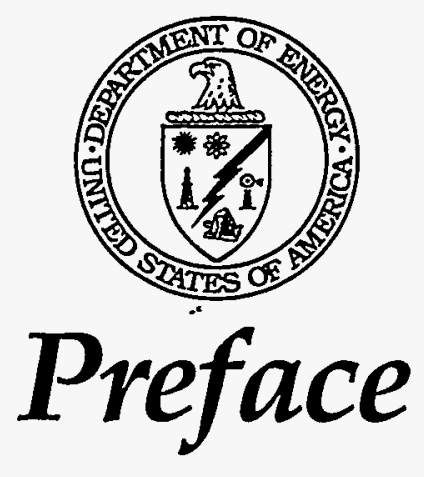

This Public Involvement Plan for the Oak Ridge Reservation (DOE/OR/ $01-1445 \& D 1$ ) was prepared in accordance with requirements of the Comprehensive Environmental Response, Compensation and Liability Act (CERCLA) for writing community relations plans. The work was performed under Work Breakdown Structure 1.4.12.2.3.01 (Activity Data Sheet 8301). Publication of this document meets a Federal Facility Agreement milestone of March 15, 1996.

This document includes information on how the DOE Oak Ridge Operations Office prepares and executes Environmental Management community relations activities.

This document supersedes the following documents:

- Community Relations Plan for the Environmental Restoration Program at the Oak Ridge Reservation, Oak Ridge, Tennessee (DOE/ORO-928), March 1991

- Public Involvement Plan for the Oak Ridge Reservation (DOE/ORO928 Rev. 1), March 1995

- Public Involvement Plan for the Oak Ridge Reservation (DOE/ORO928 Rev. 2), September 1995 



\section{DOE provides a number of information sources for you}

\section{For More Information}

For more information about the topics covered in this

publication, please contact:

Lockheed Martin Energy Systems

Community Relations Program

1-800-382-6938 (576-4006 in the local Oak Ridge calling area)

Provides information on local public involvement

opportunities and issues

Environmental Management Information Resource Center 105 Broadway Avenue

Oak Ridge, Tennessee 37830

(423) $241-4582$

Houses official Administrative Records and other environmental reports for Oak Ridge Reservation environmental cleanup work

DOE Oak Ridge Public Information Office

200 Administration Road, Federal Building

Oak Ridge, Tennessee 37831-8502

(423) 576-0885

The point of contact for DOE's Environmental

Management Community Relations Program

DOE Oak Ridge Public Reading Room

55 Jefferson Avenue

Oak Ridge, Tennessee 37830

(423) 576-1216

Electronic mail address: rothrockal@oro.doe.gov Information center for many documents concerning

DOE environmental cleanup and other decisions

Center for Environmental Management Information

1-800-736-3282 (1-800-7EMDATA)

A DOE national publication clearinghouse serving the public,

clip and save educators and industry 



\section{Contents}

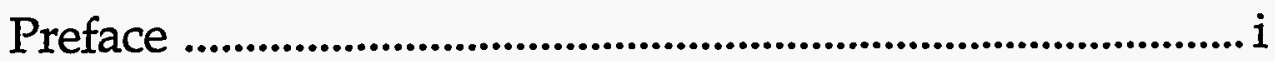

For More Information ................................................................... ii

A Letter to Stakeholders ............................................................ 1

Section I: The Public Involvement Plan .................................. 2

Section II: Public involvement in Oak Ridge ......................... 5

Section III: Public involvement in 1995 ................................. 14

Appendix A

Environmental Management in Oak Ridge........................ 19

Appendix B

Community and regional overview

Appendix C

Key laws, agreements and policy ........................................ 27

Appendix D

Principal contacts 


\section{Join DOE in its local environmental decisions}

\section{A Letter to Stakeholders}

\section{Dear Stakeholder:}

This Public Involvement Plan is your user's guide for getting involved in U.S. Department of Energy (DOE) environmental decisions in Oak Ridge, Tennessee. It outlines the many ways you can help DOE find solutions to its environmental challenges.

This plan also can help you find a level of involvement that is comfortable for you: You may wish to speak your mind on specific issues, or simply remain informed of developments and decisions. The plan tells you how to get involved and find the sources of information you need.

DOE's environmental work at Oak Ridge is a complex job involving millions of dollars, thousands of employees and dozens of companies. Your input on this work can help DOE make better environmental decisions-decisions that reflect your values and concerns. DOE has benefited from public input in several major decisions in Oak Ridge; some of these impacts are described in this plan.

If you would like to know more or give us your thoughts about the DOE public involvement process, please call the DOE Public Information Office at (423) 576-0885 or the Lockheed Martin Energy Systems Community Relations Office at 1-800-382-6938 (576-4006 within the Oak Ridge local calling area).

Sincerely,

Assistant Manager

Environmental Management

Department of Energy, Oak Ridge Operations 


\section{DOE is looking for your input}

\section{WHO IS A STAKEHOLDER?}

\section{You are.}

In the early 1990 s, as DOE

broadened its public

involvement efforts, it found

that thousands of persons

were interested in its

environmental cleanup

activities. The list included

members of environmental

groups, civic leaders,

government and contractor

employees, representatives of

environmental comparies,

labor union representatives

and members of the

general public.

All have an interest in the outcome of DOE

environmental decisions. For

some it means jobs, others a

cleaner environment. To

describe this diverse group of

interested citizens, DOE

borrowed a phrase from Gold

Rush days: Each person holds a stake-an interest-in DOE

decisions; each is a stakeholder.
Section I:

The Public

Involvement

Plan
Since it began its environmental program in the 1980s, DOE has listened to your opinions and concerns. As a result, DOE has refined and improved its approach to environmental issues and public involvement. Today, Environmental Management programs have come to depend on your input.

No two environmental projects are the same. And DOE tailors its public involvement approach for each project to ensure that you have ample time and information to express your views. Because of this, the Public Involvement Plan lists sources of information and describes commonly used public information methods.

\section{A quick tour through the plan}

Information on how the public involvement program evolved is included in Section II, along with an overview of the ways DOE works to keep you informed, hear your views and keep lines of communication open. Section III is a review of 1995 public involvement work. Throughout the sections, you will find short articles, maps and tables that provide condensed information or list sources for additional details. 


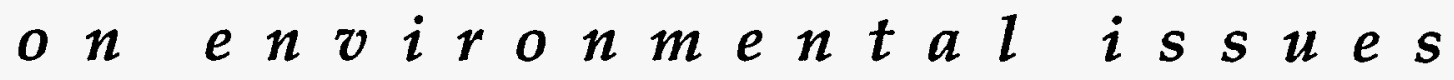

The plan's appendixes include supplemental information. Refer to these for descriptions of the DOE Oak Ridge Environmental Management Program, the Oak Ridge region and the people DOE works with.

\section{WHAT PROGRAMS DOES THIS PLAN COVER?}

The Public Involvement Plan focuses on DOE's Environmental Management public involvement activities. Environmental Management is composed of the following programs:

- Environmental Restoration

- Technology Development

- Waste Management

These are explained in greater detail in Appendix A of this plan.

Oak Ridge is the center of other well-known environmental programs. For example, scientists at Oak Ridge National Laboratory conduct research on the environment, and some research results help improve DOE's approach to environmental cleanup and waste management. Generally, such programs are not part of the DOE Environmental Management organization and are not covered in this plan. 


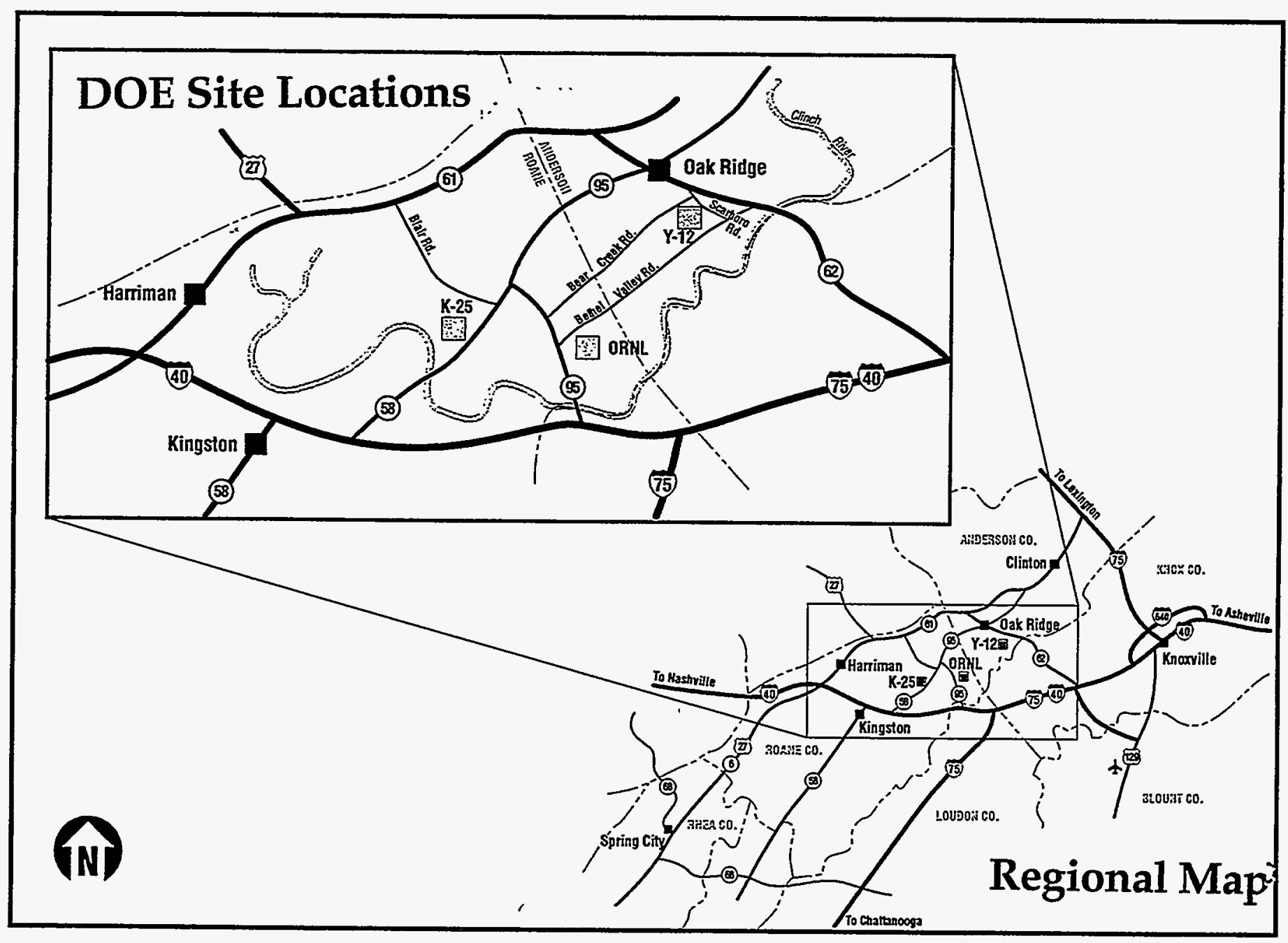

\section{Where is the Oak Ridge Reservation?}

The Oak Ridge Reservation is approximately 35,000 acres in East Tennessee. It includes portions of the city of Oak Ridge. The Clinch River surrounds the Reservation on its east and south. The land was entirely held by the federal government during the Manhattan Project effort to build the first nuclear weapon.
The Oak Ridge Reservation includes the $\mathrm{Y}-12$ Plant, the K-25 Site and the Oak Ridge National Laboratory. Each of these facilities has ongoing environmental cleanup projects.

Other area cleanup sites include:

- East Fork Poplar Creek,

- Clinch River/Watts Bar Reservoir,

- Atomic City Auto Parts,
- David Witherspoon site,

- Solway drums,

- Oak Ridge West End Sewage Digester,

- Oak Ridge Associated Universities South Campus Facility,

- CSX Railroad, and

- Elza Gate site.

More information on the Reservation and the cleanup sites is available in Appendixes A and B. 


\section{Public involvement grows in scope and reach}

\section{Section II: \\ Public involvement in Oak Ridge}

Beginning in the early 1980s, events helped reshape DOE's approach to the Oak Ridge environment. As a result of these changes, DOE was able to give you and other interested persons a larger say in its environmental decisions.

One of the first steps toward an open public involvement program began in 1983. DOE announced that mercury from the Y-12 Plant had contaminated parts of East Fork Poplar Creek and its floodplain. Mercury had been used in the production of nuclear weapons components from the 1950s through the 1970s.

Then, in 1989, the Oak Ridge Reservation was placed on the National Priorities List, which is maintained by the U.S.

Environmental Protection Agency. Sites on the list must be studied and cleaned according to the Comprehensive Environmental Response, Compensation, and Liability Act (CERCLA), often referred to as Superfund, which set national standards for cleaning hazardous waste sites.

\section{To learn more about the National Priorities List, Superfund and other laws affecting the cleanup of Oak Ridge sites, see Appendix C of this document.}

The resulting study of mercury in East Fork Poplar Creek was one of DOE's first large-scale, local cleanup efforts. By 1995, when DOE announced its plans for cleaning the creek's floodplain, the study had become a model for public input to DOE's decisions.

\section{More detail about public involvement in the East \\ Fork Poplar Creek cleanup appears in Section III of this document.}

\section{The global picture also shaped local events}

International events also had effects locally. The breakup of the Soviet Union and the Warsaw Pact in the 1980s led to the end of the decades-old Cold War. As U.S. policy focused less on large nuclear weapons stockpiles and more on the peace dividend, DOE's work in producing weapons materials lessened and its emphasis on environmental cleanup increased.

As the Cold War wound down, the need for rigorous secrecy in many DOE programs decreased. DOE was able to talk publicly about environmental concerns created by years of local weapons study and production. 


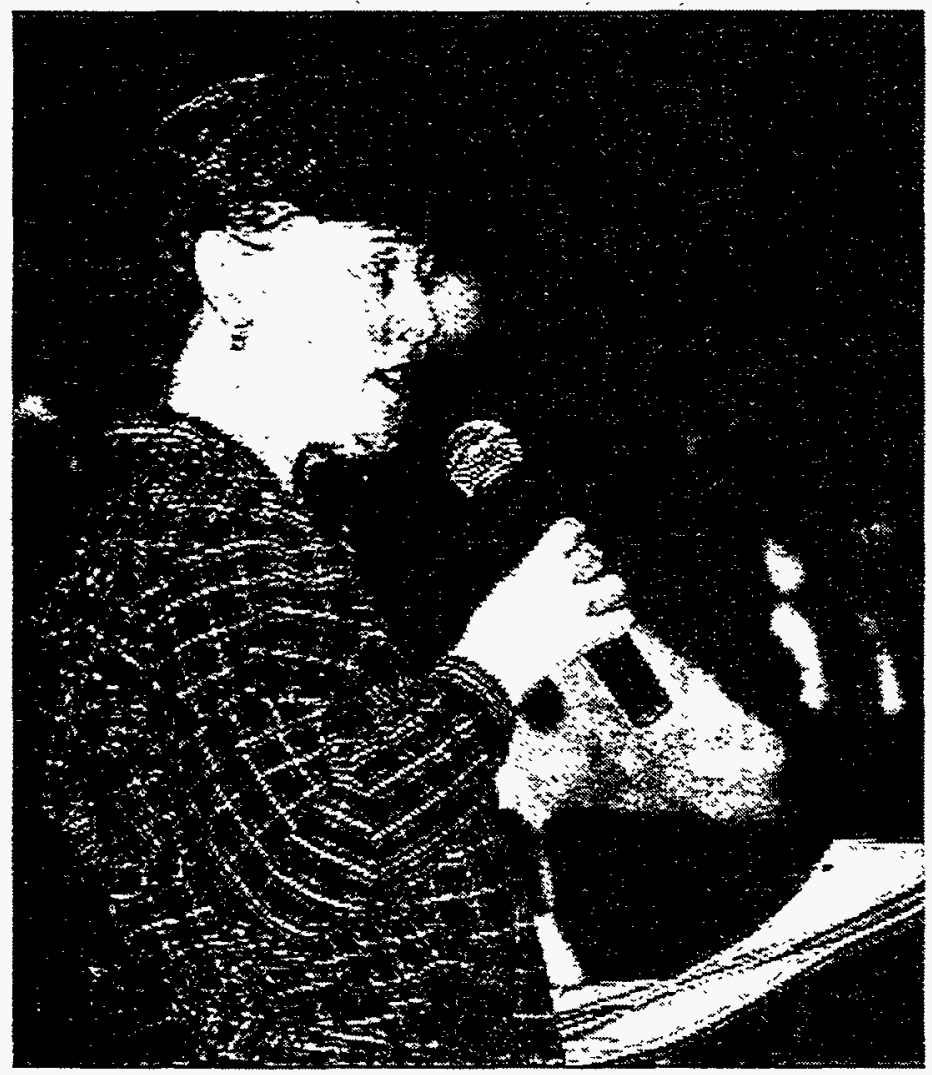

Question and answer session at a DOE public meeting.

\section{The 1990s: Increased citizen participation}

By 1990, DOE was squarely on the path to increased environmental public involvement. The benefit for you: more say in DOE environmental decisions that affect your home, health, business, or job. For DOE: better environmental decisions as it added your input to the already available information.

\section{Today's approach: Inform, listen, decide}

DOE public participation activities typically involve the following steps designed to help you learn about and participate in environmental decision making.

Include public participation in the program plan.

DOE wants to hear from you. Whether the work is managing wastes, cleaning up a contaminated area, or adopting a new technology, DOE managers include ample time and opportunities for public input.

Inform you of the opportunity for inooloement.

This generally involves announcing the opporturity through newspaper advertisements, mailings, news releases and articles in DOE's Enoironmental Update. DOE frequenily asks for comment on a specific project during a public comment period that may last 30 or more days.

\section{Provide information to you.}

For each environmental decision it faces, DOE creates reports, studies and data. These are available to you through various avenues. In most cases, DOE will send information to your home or office free or for a small fee.

DOE also publishes the Oak Ridge Reservation Annual Site Environmental Report. You can find these and other status reports in the Information Resource Center and the DOE Reading Room.

\section{More information on the Information Resource Center and the DOE}

Reading Room is available on page 9 .

DOE establishes Administrative Records for sites where environmental study and cleanup falls under Superfund regulations. Administrative Records are collections of documents that form the basis for DOE's decision about the actions required to clean the site. The Information Resource Center houses official public Administrative Records. You may obtain these at no additional charge. DOE announces the availability of Administrative Records in local newspaper advertisements. 


\section{Listen to your input.}

DOE typically offers four ways you can provide input on its environmental programs:

1. Regular stakeholder meetings are held three to four times a year. Each meeting covers a variety of topics and consists of briefings by DOE program managers, a period for your comments or questions and poster sessions where you can learn more.

2. Meetings or hearings on specific projects are scheduled as needed or required, and are usually held during public comment periods. These meetings start with a short information session followed by a time for your views or questions. Meeting locations are usually near the affected site.

3. The Oak Ridge Reservation Environmental Management Site Specific Advisory Board, a citizen's panel advising DOE's Environmental Management Program, meets monthly at sites in or around Oak Ridge. Board meetings are open, and each meeting contains a time for public input.

4. Public comment periods are held as needed to get your input on a specific project. They are announced in newspapers, mailings and the Enoironmental Update. Often, DOE holds a public meeting during the comment period; if one is not scheduled, the public can request a meeting during a public comment period. In every case, public comment periods give you an opportunity to express your views in writing.

More information on where DOE holds its Oak Ridge enoironmental public meetings is available on page 11.

\section{Weigh your input.}

Your perspective can help DOE see its programs and plans in a new light. DOE uses your input to make its final decisions about

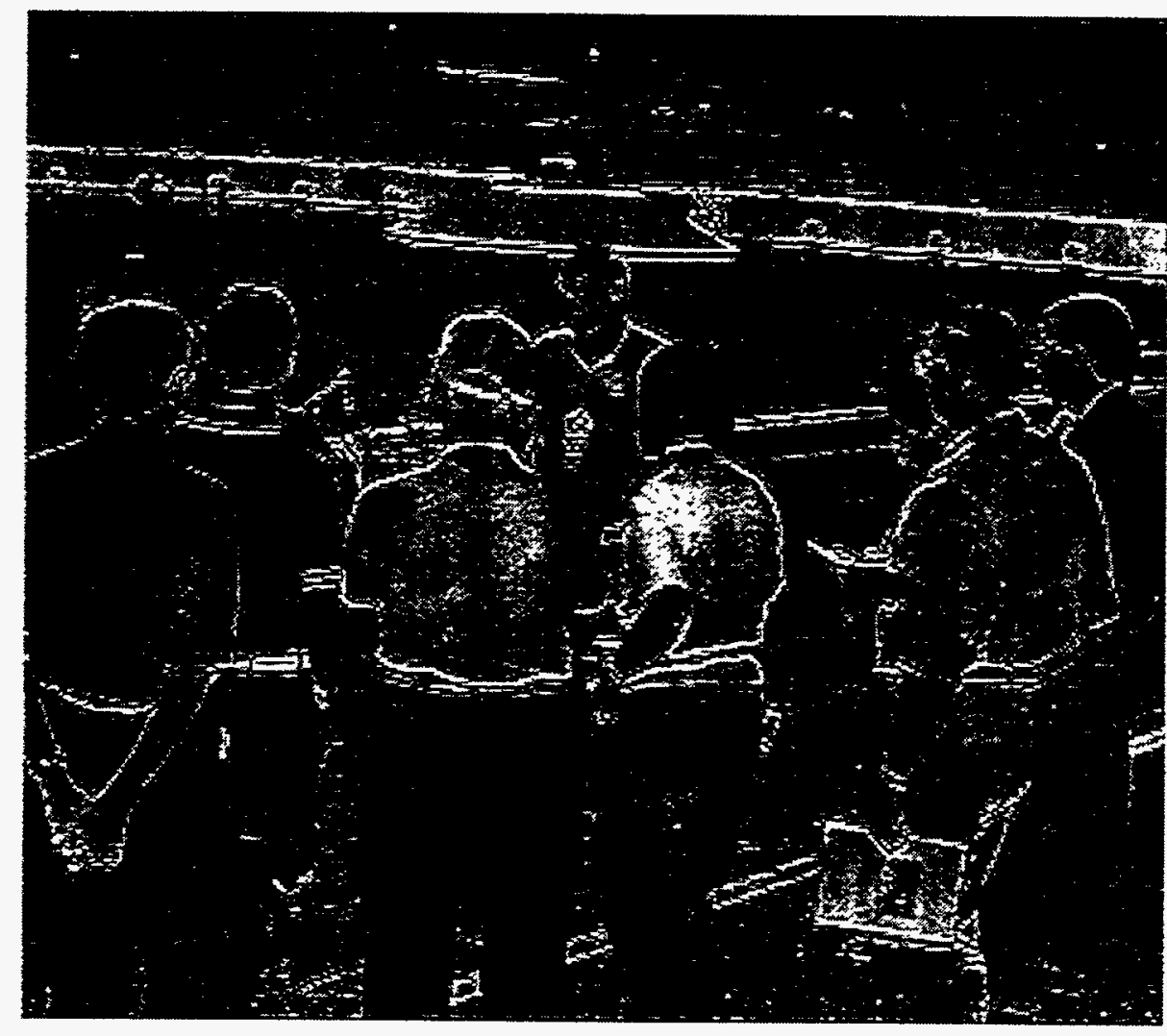

A public tour at the $X-12$ Plant in Oak Ridge.

environmental projects. Program managers weigh your views about project costs or goals along with technical data and regulatory requirements.

\section{Announce the decision.}

DOE wants you to know its decisions and how it considered your input. In some cases, an additional public meeting is held to explain the decision and the effect you had on it.

\section{Many decision documents} contain Responsiveness Summaries that show the range of comment and how their comments affected the decisions. 


\section{Other community relations methods}

Several other approaches DOE uses to gain your input on environmental issues and projects are shown below. The approach may differ from project to project.

\section{Advertisements}

Announce environmental public meetings, comment periods or document publications. The advertisements appear in area newspapers.

\section{Comment cards}

Given out at public meetings; may be handed back to a community relations staff member or mailed to the community relations office.

\section{Enoironmental Update}

A newsletter of the DOE

Environmental Management

Program containing information on specific projects. DOE

distributes nearly 40,000 copies

by mail and in local newspapers.

Call 1-800-382-6938 to have your name included on the mailing list.

\section{Informal discussion}

DOE managers want to speak with you directly to answer your questions or hear your views, and include time for informal discussions before and after public meetings.

\section{Mailings}

Announce environmental events or meetings. You may call 1-800$382-6938$ to have your name included on the mailing list.

\section{News releases}

Information provided by DOE to local newspapers, radio stations and television stations.

\section{Speakers bureau}

A group of speakers available to speak to school, civic and community organizations about environmental work in and around Oak Ridge. You may call (423) $574-4163$ to request a speaker.

\section{Tours}

DOE and its contractors will provide your group a tour of its environmental work sites. Call 1$800-382-6938$ to request a tour.

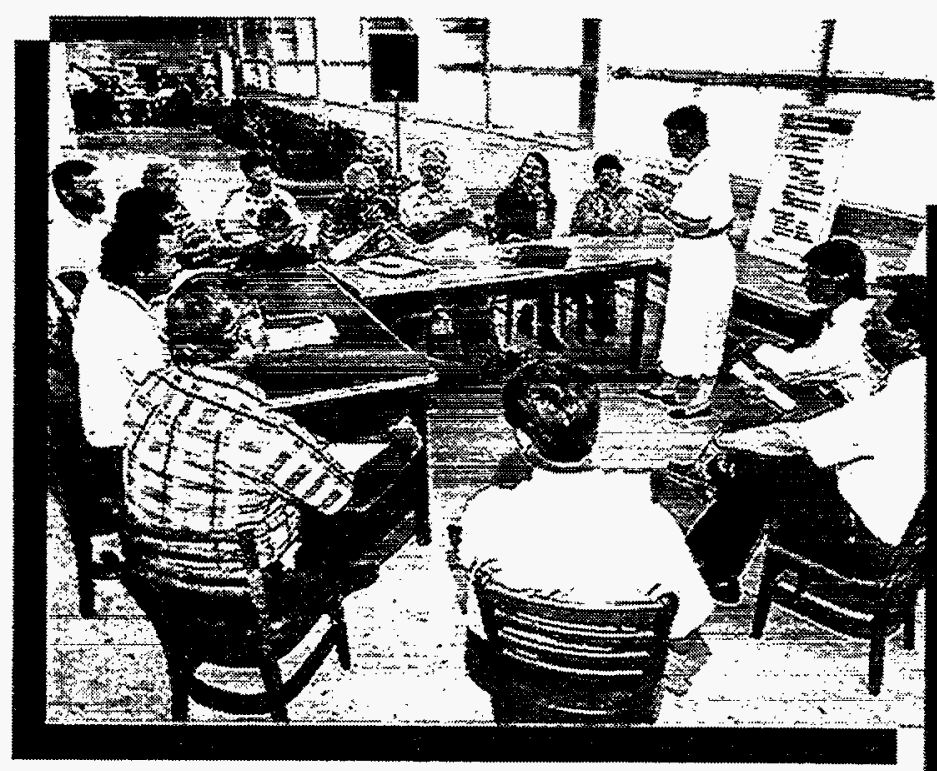

Small group listening session at a DOE public meeting.

A meeting of the Oak Ridge Reservation Environmental Management Site Specific Advisory Board. 


\section{Oak Ridge Vicinity Map}

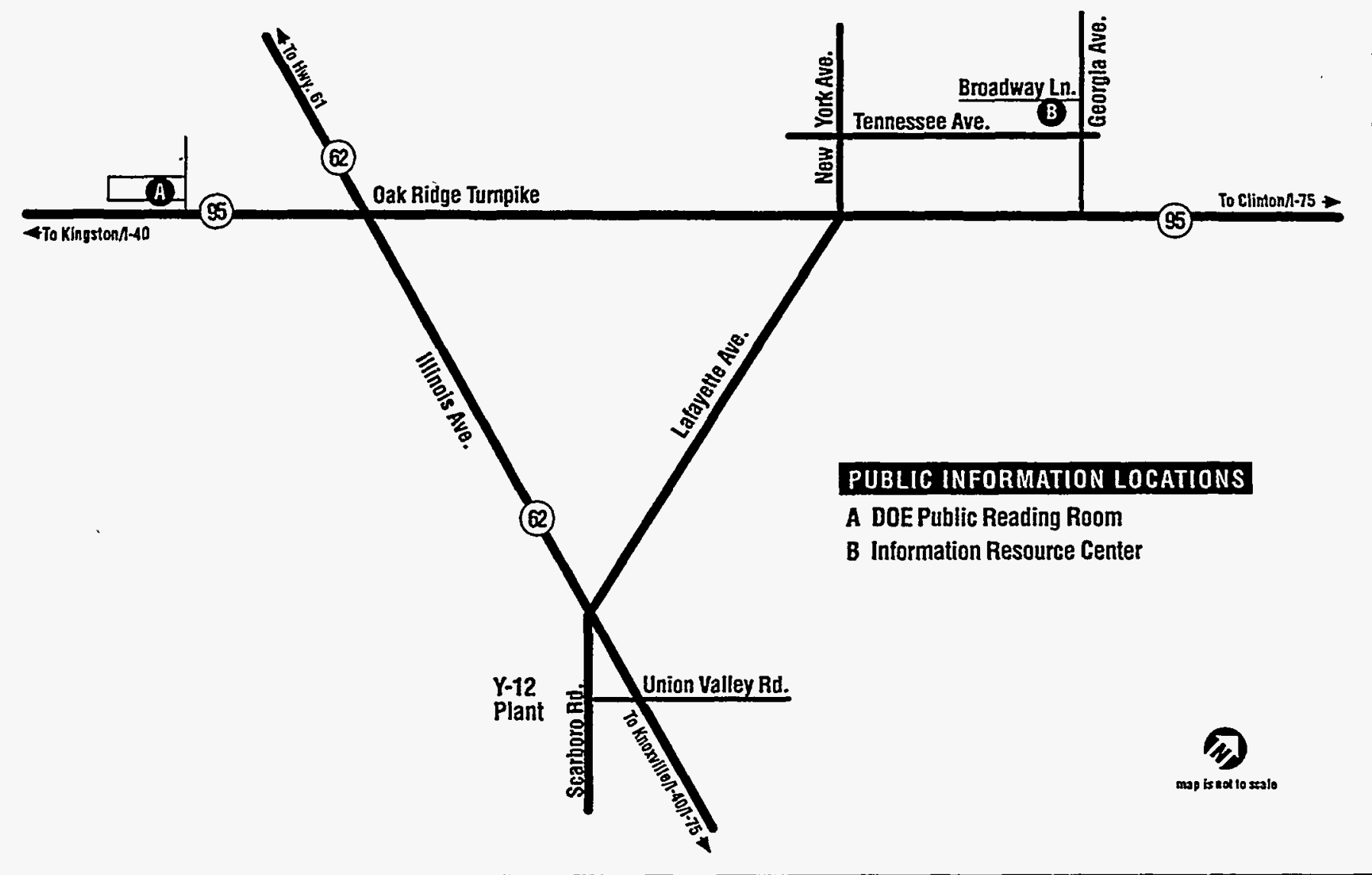

\section{Where you can find reports and studies}

DOE advertises in local newspapers when and where most new decision documents are available to you. Advertisements contain specific information on document titles, purpose and location. Generally, DOE places new and historical documents in one or both of the places listed below.

- The DOE Reading Room 55 Jefferson Avenue

Oak Ridge, TN

(423) 576-1216

Monday through Friday

8 a.m. to $11: 30$ a.m./

noon to 5 p.m.,
The reading room provides documents on the National Environmental Policy Act and other environmental topics.

- Information Resource Center 105 Broadway Avenue, Oak Ridge, TN (423) 241-4582

Monday, Wednesday and Friday 9 a.m. to 5 p.m.; Tuesday and Thursday 9 a.m. to 7 p.m.; and Saturday 9 a.m. to 1 p.m.
The center provides official public Administrative Records for Oak Ridge cleanup sites and other environmental documents.

Both locations provide indexes that you can use to find specific documents. DOE charges a small copying fee for some documents at the public reading room. 


\section{A range of comments}

\section{Your views and the views of others}

\begin{abstract}
Over the years, DOE has heard you and many others express a variety of views about its Oak Ridge environmental programs and practices. The public concerns and values are often very different and have led to lively debates among members of the public. Summarized below are many of the areas of concern that Oak Ridge stakeholders have expressed to DOE.
\end{abstract}

\section{Human health and the environment}

Stakeholders generally have agreed that DOE should ensure that the public has clean water to drink and clean air to breathe. But many sharply disagree about the effects of DOE work in Oak Ridge. While some stakeholders have stated that contamination has caused health problems in the general population and in people who work in Oak Ridge, others say they don't feel that the evidence points to adverse affects on health or the environment.

\section{The cost of cleanup}

When discussing its projected cleanup costs, DOE didn't hear only the expected "No cost too high." Instead, DOE more often heard "No. Cost too high."

Persons worried about the high cost of cleanup and the impact on taxpayers spoke loud and clear at meetings about plans for Waste Area Grouping 4 and East Fork Poplar Creek. (See "East Fork Poplar Creek" in Section III of this Plan.)

Money is not the only cost that concerned stakeholders. Many said proposed cleanup plans that call for removing large numbers of trees and large amounts of soil are more harmful to the environment than leaving some contamination in place; that the social effects of such cleanup, such as routing heavy trucks on public roads, would be a burden; and, that environmental studies are too long and needlessly lengthen cleanup schedules.

How to achieve a healthy balance between cost and effect? Stakeholders have made specific suggestions that include performing realistic cost and benefit analyses, ensuring that DOE protects and helps maintain property rights and values, performing risk assessments that used realistic assumptions, and shortening study times.

\section{Private sector waste treatment}

In 1995 and 1996, DOE asked for input on this issue and found a range of thoughts and convictions. While some said DOE should turn more of its waste treatment over to private companies, others felt DOE should treat its waste on its property.

Coupled with these feelings were concerns about transporting waste on public roads, and emissions from private companies handling DOE waste.

DOE heard from many stakeholders who felt the location of waste treatment facilities, such as the Toxic Substance Control Act incinerator on the $\mathrm{K}-25$ site, is part of a "waste corridor" that includes privately owned waste treatment facilities.

\section{Needed: Your input on the process}

Like any other DOE program, the public participation program can benefit from your input. If you have comments on how DOE approaches public outreach, or how it can do a better job of hearing or informing you, call the Lockheed Martin Energy Systems Community Relations staff toll free at 1-800-382-6938 (576-4006 within the Oak Ridge local calling area). Or, you can call or write the DOE Oak Ridge Operations Public Information Office at (423) 5760885; P.O. Box 2001, Oak Ridge, TN 37831-8502. 


\section{Oak Ridge Vicinity Map.}

PUBLIC MEETING LOCATIONS

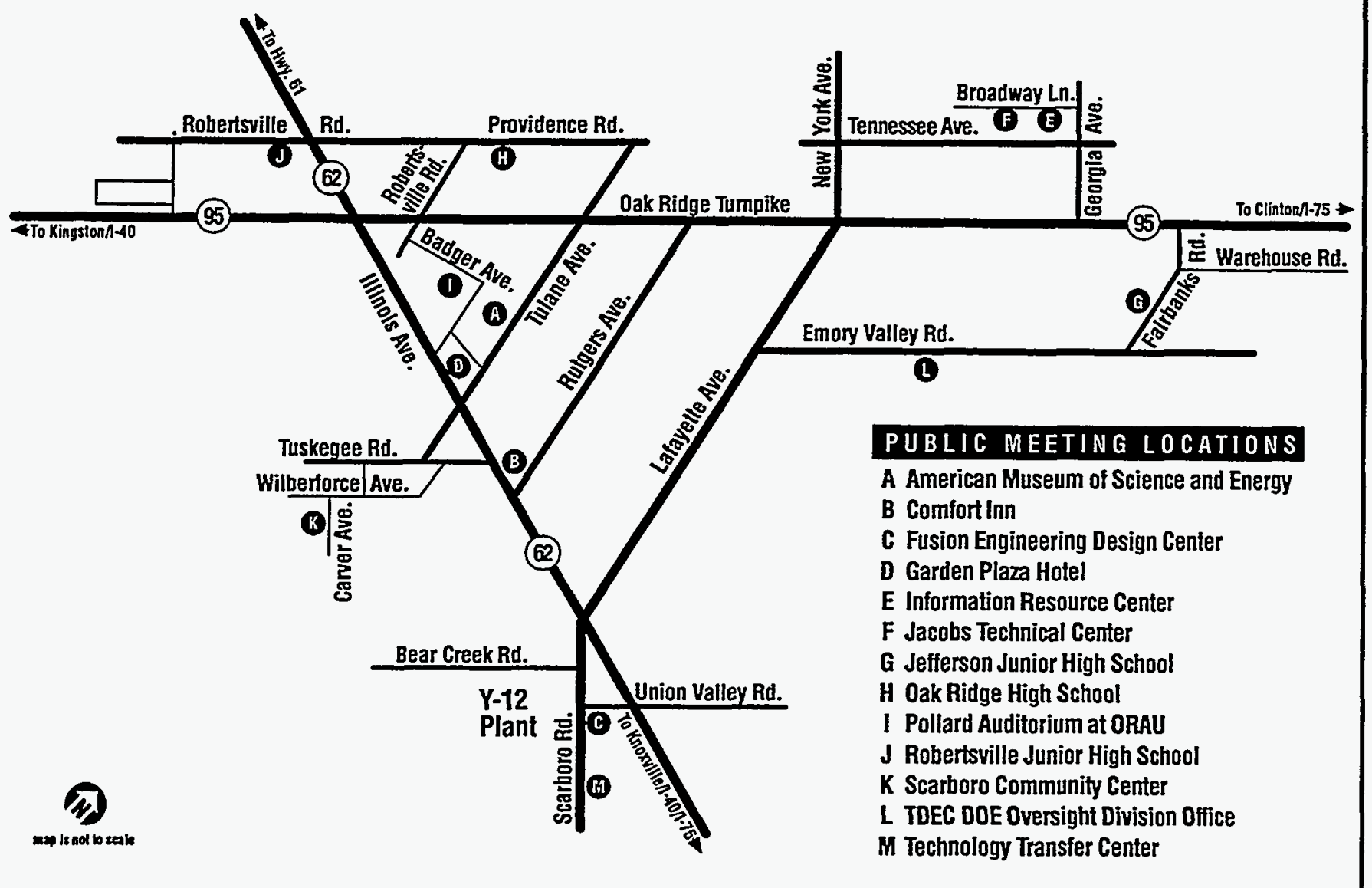

\section{Where DOE holds public meetings}

DOE holds public meetings at or near sites affected by its environmental decisions. For example, 1995 meetings concerning plans for the Lower Watts Bar Reservoir were held in Kingston and Spring City, Tennessee. Most meetings are held in and around Oak Ridge.
Announcements for DOE public meetings include the time and location and provide a telephone number you can call for additional information. DOE chooses meeting locations with access for persons with disabilities.
Your ideas made an impact in 1995. Two major projects-East Fork Poplar Creek and formation of the Site Specific Advisory Board-and several smaller efforts were completed. 


\section{Your views helped shape DOE}

Clinton \& Spring City Maps

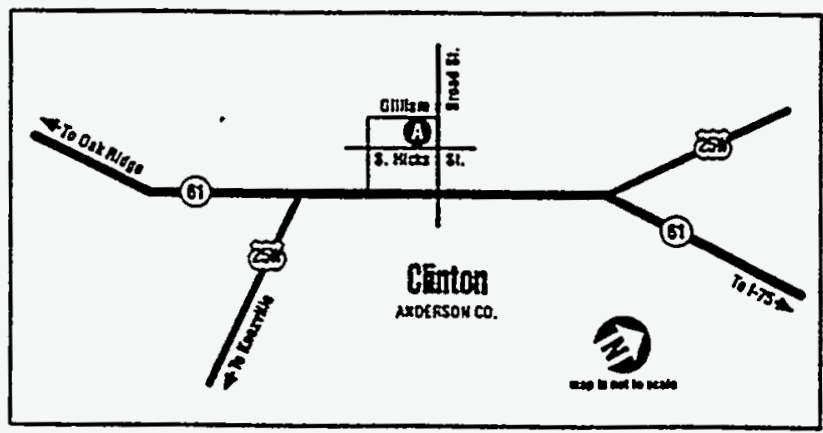

PUBLIC AAETIHG LOCATIOHS

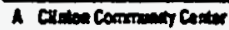

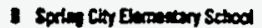

PUBLIC MEETING LOCATIONS

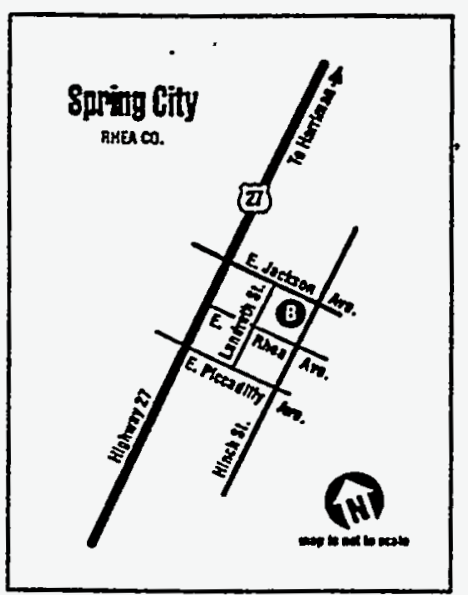

Roane County Area Map

PUBLIC MEETING LOCATIOHS

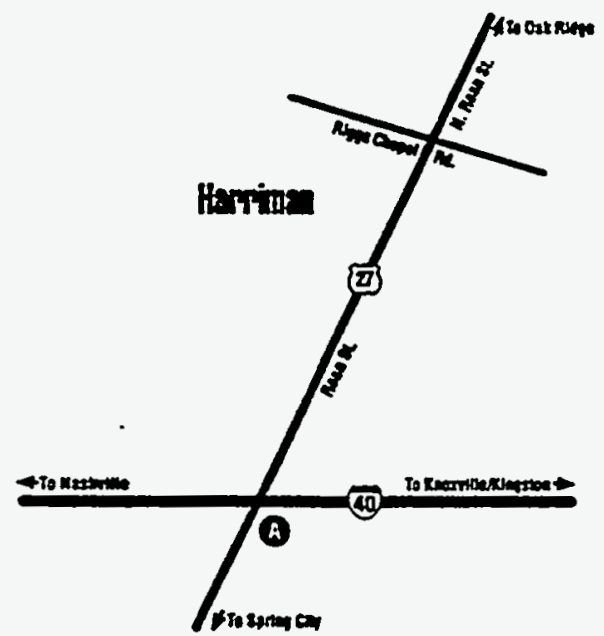

AII

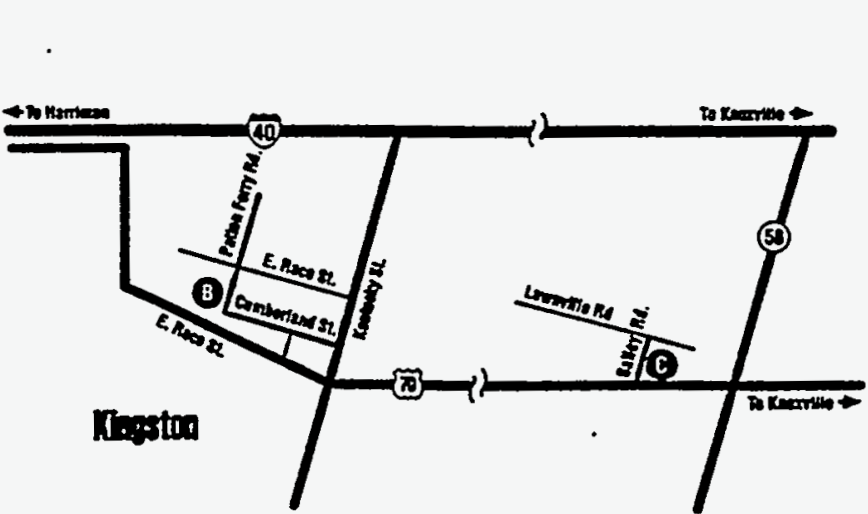

PUBLIE BEETING LOCATIOUS

A Hatrinattiler in

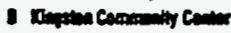

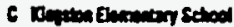




\section{environmental decisions}

\section{Section III: \\ Public involvement in 1995}

\section{East Fork Poplar Creek}

DOE listened closely to stakeholder views as it neared a final decision about how it would clean mercury from the creek's floodplain. DOE's studies had shown where the creek and its floodplain were contaminated with mercury; the decision centered on cleanup levels.

Throughout the process, DOE had actively sought public comment. DOE had established a special citizen's working group to provide input on East Fork Poplar Creek cleanup and had held public listening sessions to hear issues.

More than 175 people attended a public meeting in January 1995

where representatives from DOE, the Tennessee Department of Environment and

Conservation and the U.S. Environmental Protection Agency announced a plan for removing mercury from the floodplain. Stakeholders at the meeting reacted to the plan as taxpayers, property owners and persons worried about the environment. The overwhelming message: DOE should remove high levels of mercury from the creek but not incur huge project costs or cause additional environmental harm.
DOE rethought its proposed plan and continued work to hear public views. Three tours of the creek were scheduled for February 1995.

DOE also completed a risk analysis that considered the type and toxicity of the floodplain mercury; the data showed the potential health effects were not as severe as originally thought. This study, in tandem with public comment, led DOE to a new plan: It proposed to clean only those areas of the floodplain where mercury levels exceeded 400 parts per million. The resulting changes would mean the work could be completed faster, cheaper and with less impact on the local environment while protecting people's health and the environment. While some stakeholders at a June public meeting asked DOE to keep the originally planned stringent cleanup levels, many others lauded the new plan. DOE and its environmental regulators signed a Record of Decision in September 1995 that used the 400 parts per million cleanup standard..

\section{Site Specific Advisory Board}

In early 1995, DOE held a series of information meetings aimed at creating a new Site Specific
Advisory Board. The local board would be one of many citizen's boards formed around the nation to advise DOE environmental managers.

The information meetings allowed DOE to talk about its expectations for the board and to hear the public's views on potential board members and future agenda topics.

To select board members, DOE took applications from interested persons and created a seven-member screening panel. The screening panel reviewed applications to ensure makeup of the board met diversity standards of the Federal Advisory Committee Act.

By late 1995, DOE and the screening panel had done their work. A 20-member board had been formed and was holding organizational meetings. The board holds public meetings monthly on or near the Oak Ridge Reservation. Meetings are advertised in local newspapers, the Federal Register, and through mailings. 


\section{Other agencies participating in local public involvement}

DOE shares the Oak Ridge environmental public involvement stage with state and local boards and agencies. Some of the other groups that hold public meetings in Oak Ridge include:

\section{Tennessee Department of Environment} and Conservation

\section{DOE Oversight Office}

State agency with regulatory and review roles over many Oak Ridge Environmental Management activities. Holds regular meetings on local environmental issues.

\section{Oak Ridge Reservation Local Oversight Committee}

Independent committee composed of elected officials and citizens from the Oak Ridge area and adjacent counties. Seeks to improve public understanding of Environmental Management activities on the Oak Ridge Reservation. Also, identifies issues of local concern regarding Oak Ridge environmental management activities.

\section{Oak Ridge Environmental Quality Advisory Board} Committee that makes recommendations on environmental issues to the Oak Ridge City Council.

\section{Roane County Environmental Review Board}

Independent board advising the Roane County Commission on environmental matters. 


\section{Other Activities}

In 1995, a number of other environmental public involvement efforts were conducted.

- DOE held three public meetings covering several environmental topics (April, July, November).

- DOE held waste management stakeholder information session on proposed site treatment plan (January).

- DOE mailed three issues of the Enoironmental Update (April, July, November).

- DOE sponsored a workshop to get input on cleaning up contaminated ponds at Oak Ridge National Laboratory (March).

- DOE held two public meetings on plans for cleaning contaminants from Lower Watts Bar Reservoir (April).

- DOE held a public meeting for waste management stakeholders; topics inciuded private sector involvement in treating DOE waste (April).

- DOE started its toll-free telephone line service, 1-800-382-6938 (March).

- DOE held a scoping meeting on the Programmatic Environmental Assessment for private-sector treatment of DOE mixed waste (June).

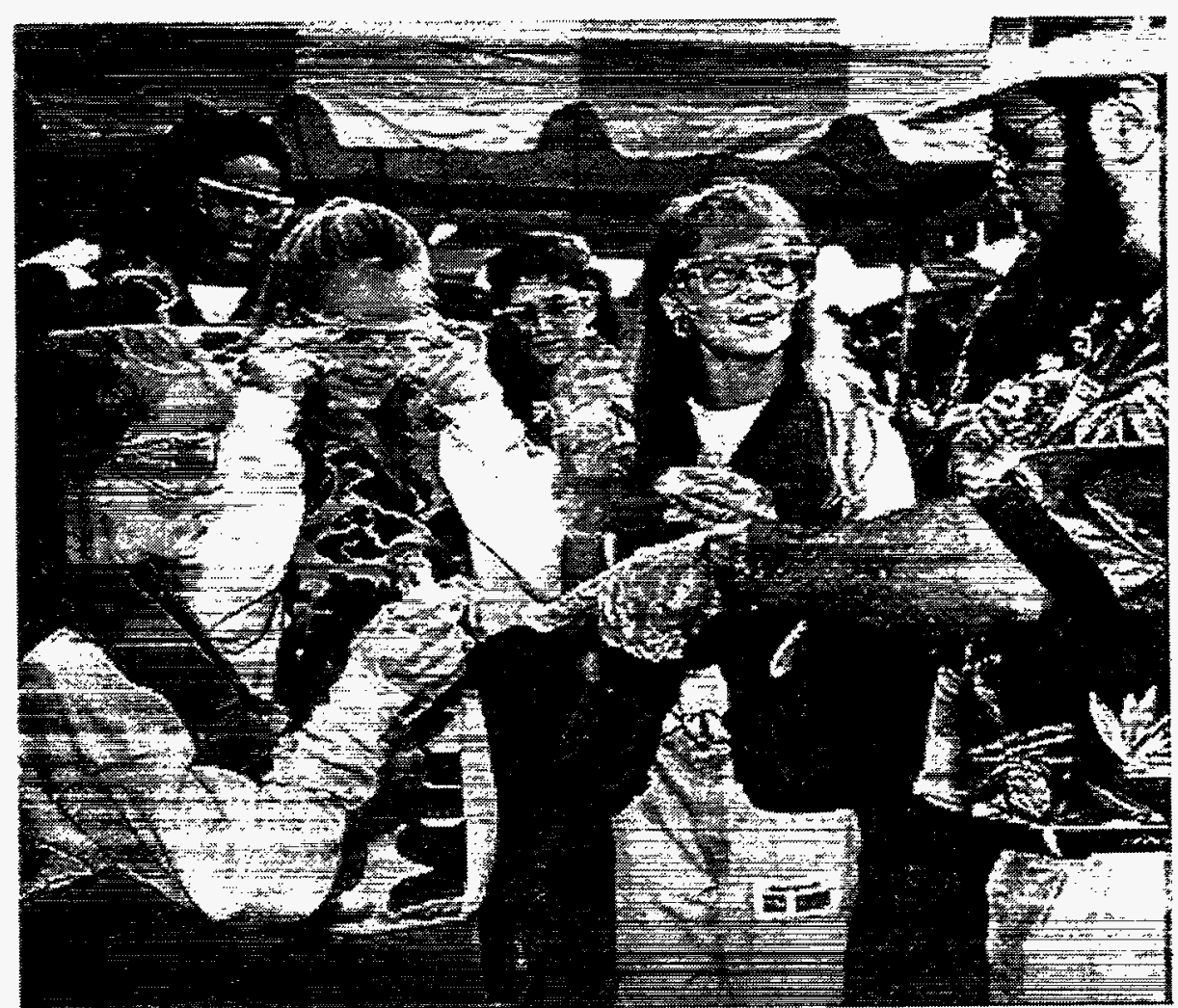

Students at the 1995 EnvironMENTAL Fair.

- DOE ran an announcement and held a public comment period for the Chestnut Ridge Filled Coal-Ash Pond Proposed Plan. The topic was also discussed in a stakeholders meeting (July).

- DOE held a public workshop on the Baseline

Environmental Management Report (August).

- DOE held a workshop on the Molten Salt Reactor Experiment remedial action program at Oak Ridge National Laboratory (October)
- DOE held the fourth annual EnvironMENTAL Fair for students from local elementary and middle schools (October).

- DOE sponsored a video conference on the Draft Waste Management Programmatic Environmental Impact Statement (October).

- DOE held meetings with members of the Merriwater Homepark Association concerning testing of ground water in their neighborhood (December). 



\section{APPENDIX A}

Environmental Management

In Oak Ridge 



\section{Environmental Management in Oak Ridge}

Hazardous and radioactive wastes have been and are still being generated at the three principal sites comprising DOE's Oak Ridge Reservation-Oak Ridge National Laboratory, the Y-12 Plant and the K-25 Site. In some cases, contamination has traveled away from these sites to areas that are not part of the government lands in Oak Ridge. DOE's efforts to reduce or eliminate risks posed to human heaith and the environment from both on- and off-site contamination fall into three categories-environmental restoration, waste management and development of new technologies to solve environmental problems. DOE is now aggressively facing the challenge of cleaning up its Oak Ridge Reservation while conducting environmentally responsible operations.

\section{Oak Ridge National Laboratory}

From its original war-time objective of demonstrating that plutonium could be produced from uranium, ORNL's mission has evolved to performing basic scientific research in the physical and life sciences. ORNL now has more than 200 sites on its 2,900 acres that are contaminated with hazardous waste, transuranic (heavier than uranium) waste and liquid and solid low-level radioactive and mixed (both radioactive and hazardous) wastes. Sixteen of ORNL's buildings are on the list to be cleaned up and either used for another purpose or torn down.

\section{The Y-12 Plant}

The $Y-12$ Plant processed the first uranium-235 for use in nuclear weapons and continued to manufacture nuclear weapons components throughout the Cold War and into the late 1980s. With the end of the Cold War, the plant's 811 acres are now devoted to dismantling and

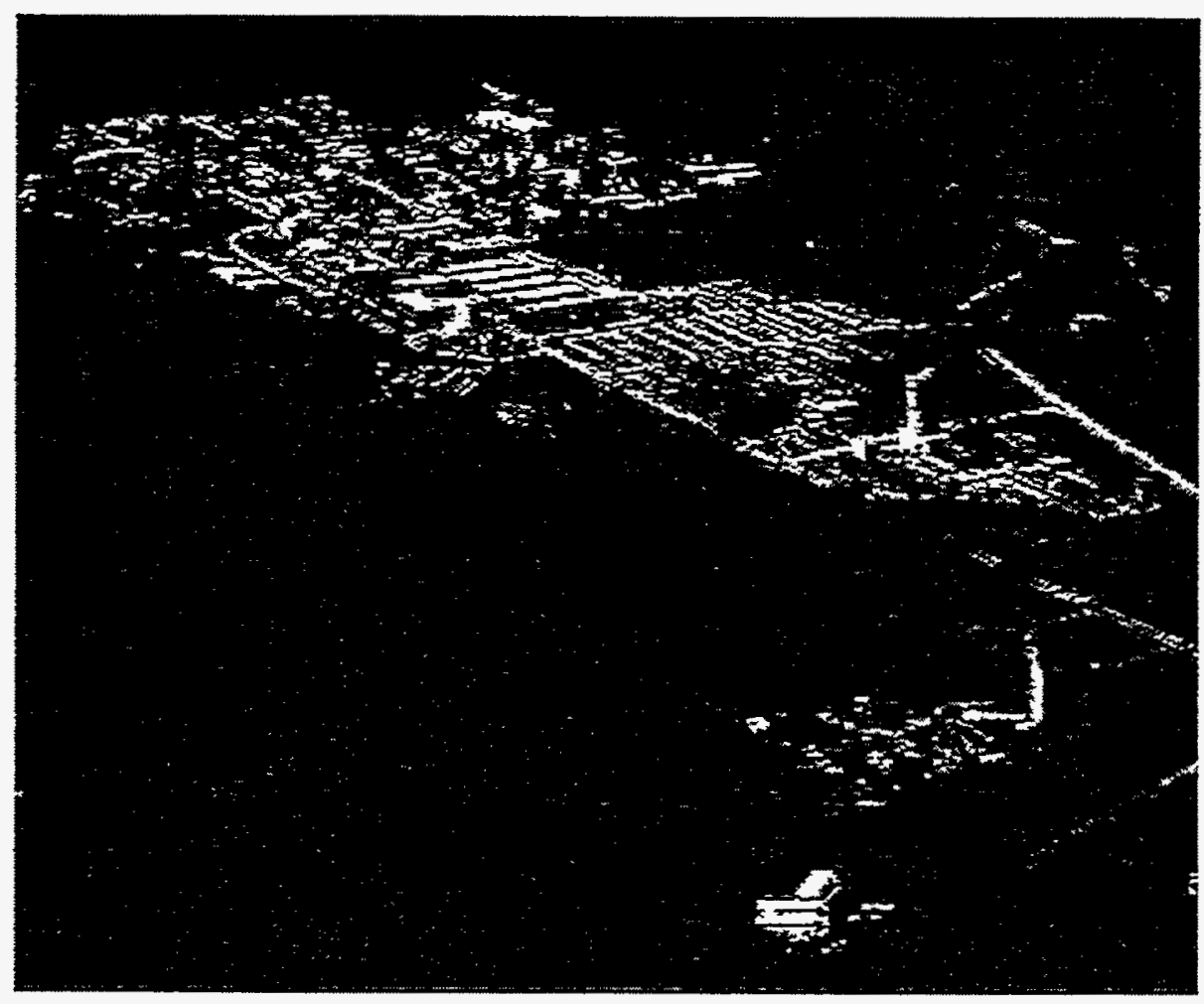

Oak Ridge National Laboratory 
storing nuclear weapons components, maintaining a storehouse of weapons-grade nuclear materials and the nation's nuclear weapons production capability and applying its unique

manufacturing expertise to private, nonmilitary endeavors. It was mercury from $Y-12$ that migrated through East Fork Poplar Creek into the city of Oak Ridge. On-site waste disposal areas, storage tanks and spill sites, along with the 4.5-acre "Alpha-5" building, are also slated for cleanup or continuous monitoring.

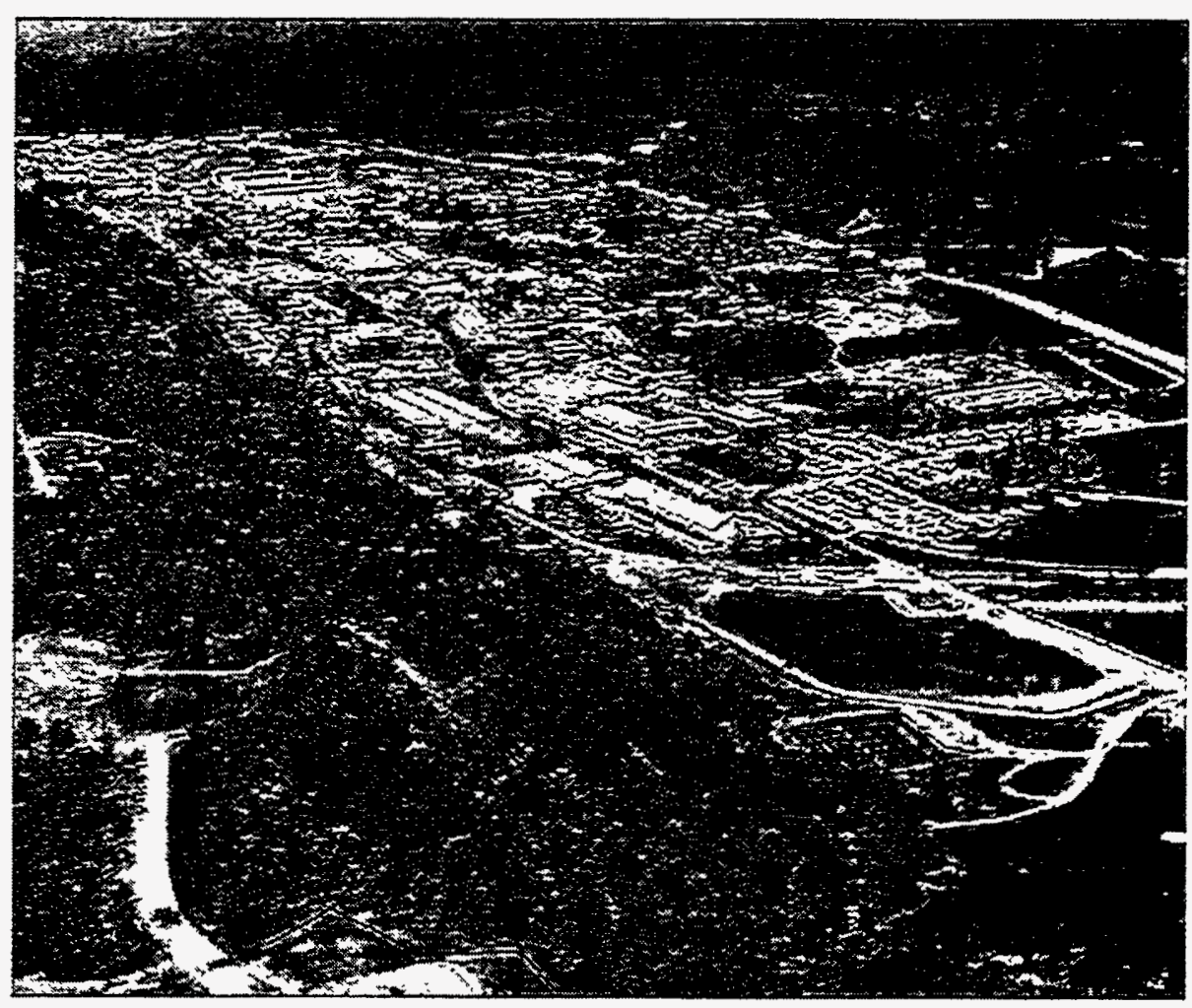

Y-12 Plant

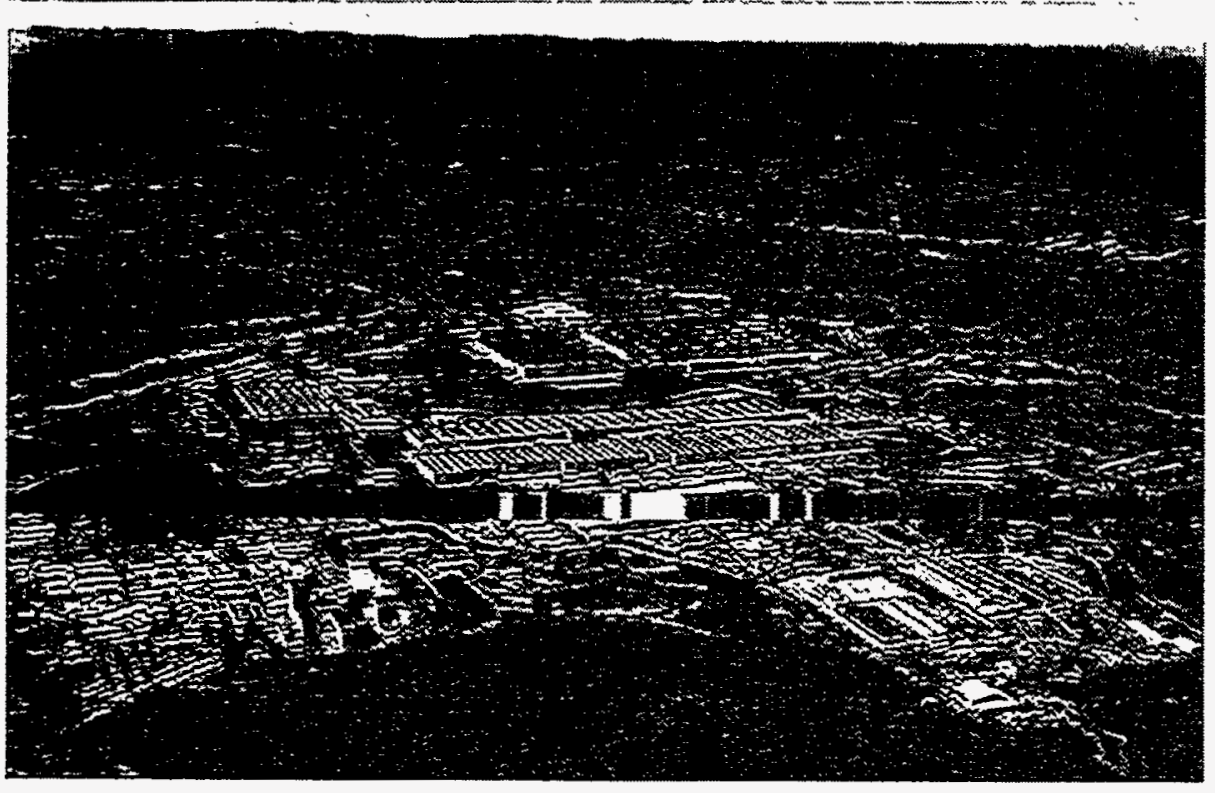

K-25 Site

\section{The K-25 Site}

Formerly known as the Oak Ridge Gaseous Diffusion Plant, the K-25 Site housed the world's first uranium enrichment facility that used the gaseous diffusion process. After World War II, K-25 supplied enriched uranium for the nation's defernse and later for the nuclear power industry. When its production was shut down in the mid 1980s, the site's 4,845 acres became the headquarters for DOE's Environmental Management Program and home to the only waste incinerator in the country licensed to bum both hazardous and low-level radioactive wastes. About 86 of the site's 340 buildings are scheduled for cleanup and reuse or demolition. $\mathrm{K}-25$ ' $\mathrm{s}$ waste sites include burial grounds, storage facilities, underground tanks, waste ponds and treatment facilities. 


\section{Environmental Restoration}

Low-level radioactive, hazardous and mixed wasies are present in soil, ground water, surface water, buildings and equipment throughout DOE's Oak Ridge Reservation. Since 1989 , when the Reservation was placed on the

U.S. Environmental Protection Agency's Superfund list of sites most in need of cleanup, a number of projects have been successfully completed. DOE has

\section{- placed caps on 114} contaminated acres to prevent rainwater from carrying the contaminants away from the Reservation;

- closed 28 surface storage areas;

- developed 503,556 square feet of waste storage space;

- removed 13 miles of asbestos pipe insulation;

- cleaned or disposed of 13,867 pieces of equipment contaminated with PCBs (polychlorinated biphenyls);

- removed 700,000 cubic feet of contaminated soil;

- recycled 5 million pounds of scrap metal; and

- treated and cleaned 50 million gallons of surface and ground water.

\section{Waste Management}

In addition to cleaning up wastes from past operations, DOE works to minimize waste generation in its current operations, reduce wastes, decrease waste storage and disposal costs and reduce health risks to its workers. The Waste Management Program also

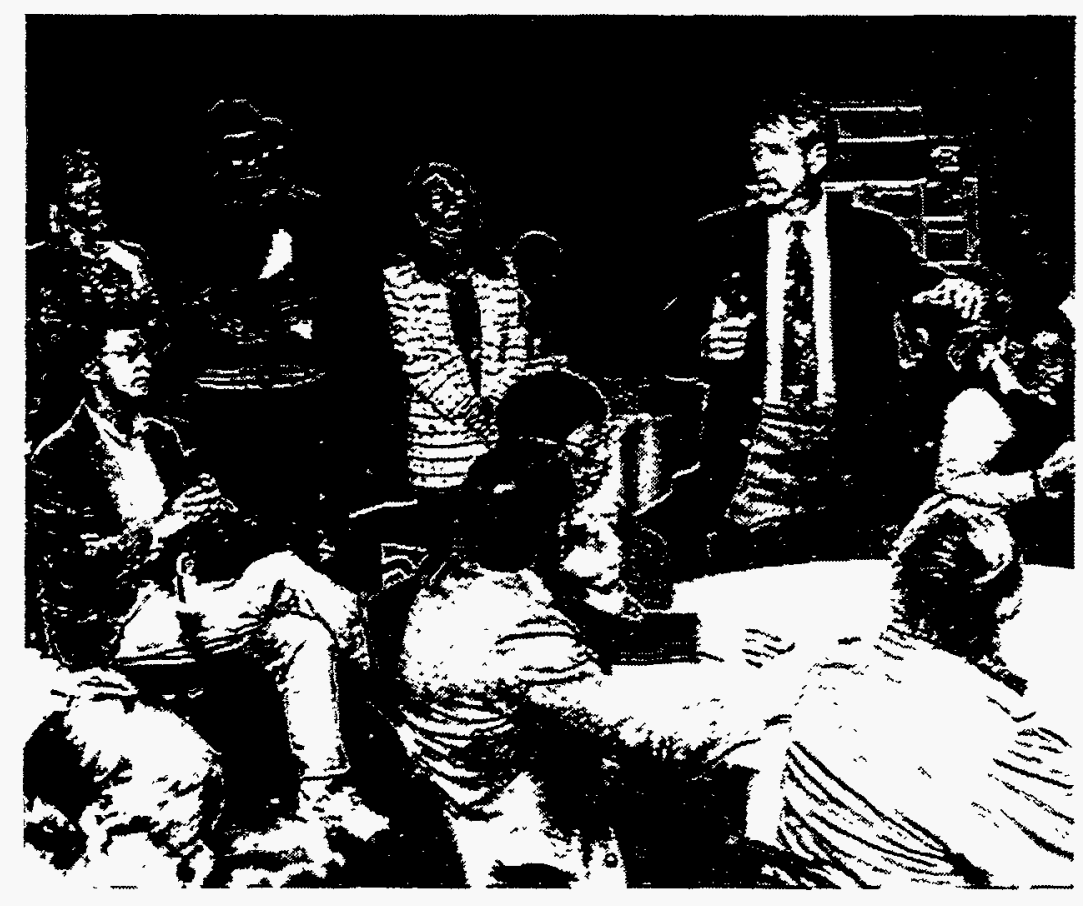

Answering stakeholder questions at a DOE public meeting.

directs the safe treatment, storage and disposal of wastes generated by past and current operations and from environmental restoration projects.

To minimize waste generation, DOE is

- increasing the use of nonhazardous chemicals;

- designing or redesigning products, processes and facilities to produce less waste;

- reusing and recycling items whenever possible; and

- educating employees on ways to create less waste.

\section{Technology Development}

The challenge of cleaning up and managing DOE's hazardous and radioactive wastes often demands developing new or modifying existing technologies. For example, researchers are developing microorganisms to degrade or stabilize certain organic contaminants such as PCBs and inorganic elements such as uranium, chromium and lead. Robotic systems are being studied as a way to characterize and clean up waste without exposing workers to the hazardous environment. New sensing and monitoring devices, new ways to package waste for transportation and storage and new methods to treat and store wastes are being researched and demonstrated. DOE is also looking at ways that these new technologies can be applied in its Environmental Management Program, private industry, academia and with other federal agencies. 


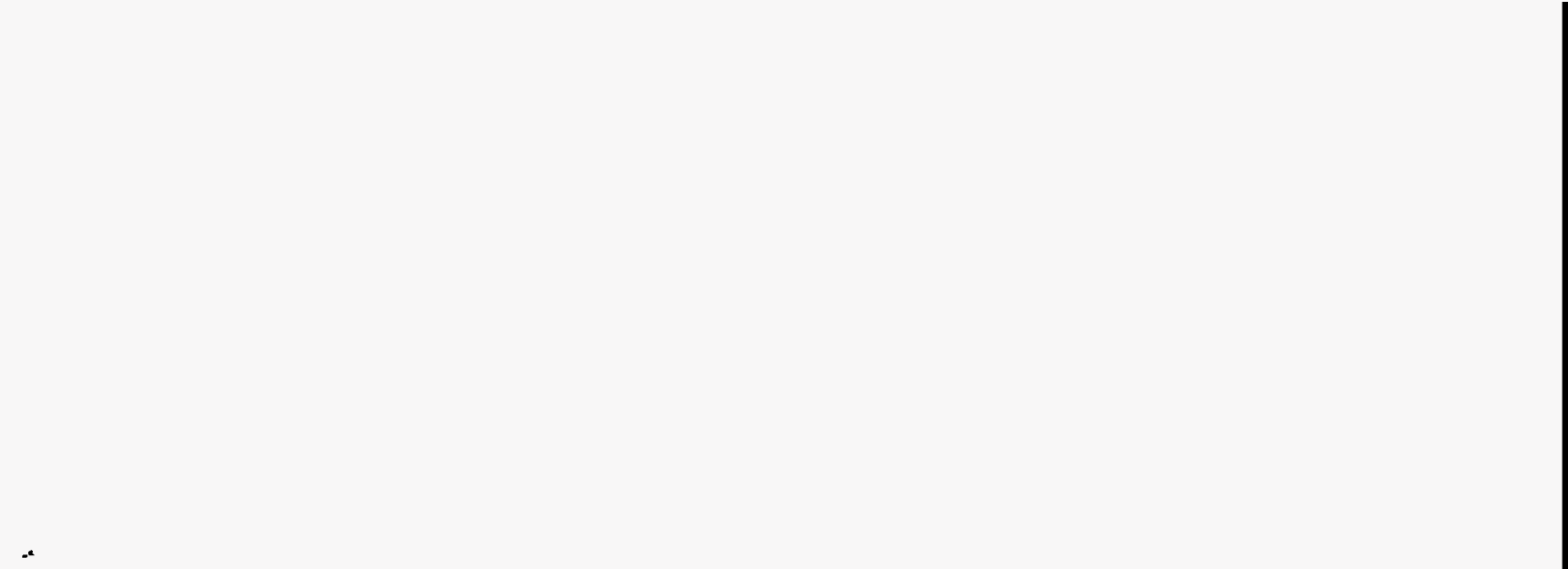




\section{APPENDIX B}

\section{Community and Regional Overview}




\section{Community and regional overview}

Fifty years ago, the federal government bought 59,000 acres of farmland in Anderson and Roane counties to house portions of the government's secret World War II Manhattan Project. In the 1950s, some of that land was released from federal ownership and became the city of Oak Ridge. Today, more than half of that remains as DOE's Oak Ridge Reservation, which includes the Y-12 Plant, Oak Ridge National Laboratory and the K-25 Site.

The Reservation extends 11 miles east-to-west and eight miles north-to-south and is bordered on its south and east by the Clinch River. Eight counties (Anderson, Blount, Knox, Loudon, Meigs, Morgan, Rhea and Roane) surround the Reservation. Most of the land close to the Reservation (including land within the cities of Oak Ridge, Oliver Springs, Clinton, Farragut and Knoxville) is used for housing and commercial purposes.

Of the 618,000 people who live in the eight counties surrounding the Reservation, more than 340,000 are concentrated in the Knoxville/ Knox County area. More than 27,000 live in Oak Ridge. The average person living in the area is 35 years old with an annual individual income of $\$ 11,272$. Average household income is $\$ 23,241$. About $30 \%$ of persons 25 and older are high school graduates; about $12 \%$ are college graduates.

Almost 300,000 people comprise the area's work force. The three largest employers are Lockheed Martin Energy Systems, Inc., and Lockheed Martin Energy Research, which operates Oak Ridge National Laboratory; the Knox County School System; and the University of Tennessee.

The area's economic base supports a large number of hightech industries that conduct business with DOE. In 1994, DOE and the companies it contracted employed about 20,000 workers who together earned about $\$ 891$ million annually. More than $90 \%$ of these workers lived in Anderson, Knox, Loudon and Roane counties. 



\section{APPENDIX C}

Key Laws, Agreements and Policy 



\section{Key laws, agreements and policy}

\section{Federal laws}

CERCLA, also referred to as Superfund,

- requires companies and federal agencies to investigate and remedy abandoned or uncontrolled hazardous waste sites;

- sets standards for studying and cleaning contaminated sites;

- requires the U.S. Environmental Protection Agency to maintain the National Priorities List;

- requires the agency or company performing the cleanup to write a community relations plan and have a community relations program for ensuring public input; and

- requires an Administrative Record and information repository (in Oak Ridge, the Information Resource Center).

\section{Resource Conservation and Recovery Act (RCRA)}

- sets standards for managing hazardous waste facilities,

- sets standards for dealing with hazardous waste releases,

- establishes a permitting system for handling hazardous wastes,

- encourages permit applicants to develop public involvement programs, and

- gives states authority to regulate hazardous wastes,

\section{National Environmental Policy Act (NEPA)}

- requires federal agencies to consider and document environmental consequences of their actions and

- requires federal agencies to perform environmental assessments and write Environmental Impact Statements for work posing potential harm to the environment.

\section{Federal Facilities Compliance Act}

- amends the Resource Conservation and Recovery Act and

- requires state regulators and federal agencies to develop a consent order for treating and storing mixed waste (see following). 


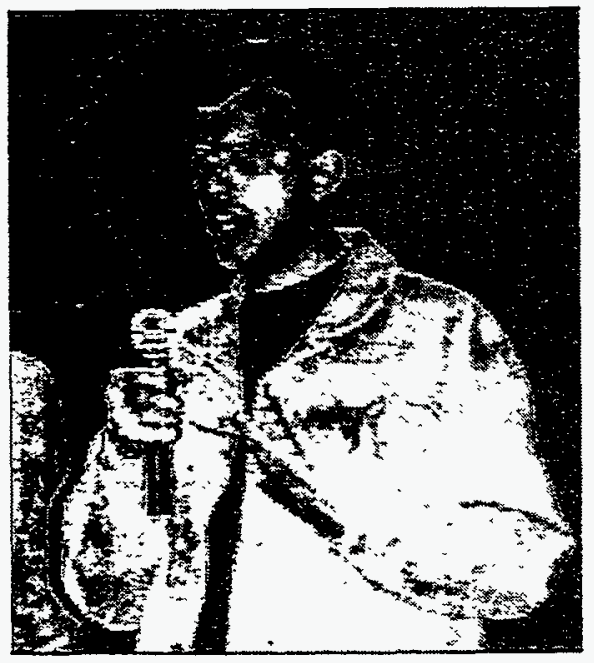

Making a point during a public meeting.

\section{Agreements and policy}

Federal Facility Agreement

- is signed by DOE, the Tennessee Department of Environment and Conservation and the U.S. Environmental Protection Agency;

- sets requirements and schedules for environmental restoration work on the Reservation; and

- requires a community relations plan.

\section{Consent Order}

- is required by the Federal Facilities Compliance Act and

- specifies a schedule for treating and storing mixed wastes on the Oak Ridge Reservation.

\section{Presidential policy on Environmental Justice}

- directs all federal agencies to "identify and address disproportionately high and adverse human health or environmental effects of its programs, policies and activities on minority populations and low-income populations..." 
APPENDIX D
Principal Contacts 



\section{Principal contacts}

This appendix lists officials and organizations frequently contacted by the Environmental Management Community Relations staff. The appendix does not include the complete Community Relations mailing list. For example, the names of private citizens are not provided here. Organizations wishing to appear in future revisions of the Community Relations plan, or persons wishing to be added to the Community Relations mailing list, should call 1-800-382-6938 (576-4006 in the Oak Ridge local calling area).

\section{United States Senators Bill Frist}

U.S. Senate

Fred D. Thompson

U.S. Senate

\section{United States House of Representatives James J. Duncan \\ House of Representatives Tennessee Șecond Congressional District}

\section{Zach Wamp} House of Representatives Tennessee Third Congressional District

Van Hilleary House of Representatives Tennessee Fourth Congressional District

\section{Tennessee Governor \\ Donald Sundquist} Governor of Tennessee

Tennessee State Senate Randy McNally Fifth Senate District

Anna Belle O'Brien Twelfth Senate District

Gene Elsea Thirteenth Senate District

\section{Tennessee State House \\ Chris Newton}

Twenty-second House District

David Coffey

Thirty-third House District

Bruce Cantrell

Thirty-second House District

Jerry Cross Thirty-sixth House District

County Executives

David Bolling Anderson County Executive

Thomas Schumpert Knox County Executive

George Miller Loudon County Executive

Garland Lankford Meigs County Executive

Tommy Kilby Morgan County Executive

Billy Ray Patton Rhea County Executive

Kenneth E. Yager Roane County Executive

Tennessee City Contacts Sam Swafford, Mayor City of Dayton
Garland Carpenter, Mayor Town of Decatur

Edward Ford, Mayor

City of Farragut

Andy Beene, Mayor City of Graysville

Harold Wester, Mayor City of Harriman

Don Woody, Mayor City of Kingston

Victor Ashe, Mayor City of Knoxville

Kathleen D. Moore, Mayor City of Oak Ridge

Stanley Justice, Mayor City of Oliver Springs

Mike Miller, Mayor City of Rockwood

Mike Swafford, Mayor City of Spring City

Ellen Smith Environmental Quality Advisory Board City of Oak Ridge

Department of Energy, Oak Ridge Operations James C. Hall, Manager Oak Ridge Operations 
R.R. Nelson

Assistant Manager for

Environmental Management

Steven L. Wyatt

Assistant to the Manager for

Public Information

Walter Perry

Community Relations

Manager

Sandy Perkins

Site Specific Advisory Board

Coordinator

Patty Phillips.

National Environmental

Policy Act Compliance Officer

Federal, State and Local

Agencies

Jack Hanley

Agency for Toxic Substances

and Disease Registry

U.S. Public Health Service

Jon Johnston

U.S. Environmental

Protection Agency

Region N, Atlanta, GA

\section{Earl Leming}

Tennessee Department of

Environment and

Conservation

DOE Oversight Division

Oak Ridge, Tennessee
David McKinney

Tennessee Wildlife Resources

Agency

Crossville, Tennessee

Pat Turri

Tennessee Department of

Health

Nashville, Tennessee

Amy Fitzgerald

Oak Ridge Reservation Local

Oversight Committee

Oak Ridge, Tennessee

Elgan Usrey

Tennessee Emergency

Management Agency

Nashville, Tennessee

Civic, Environmental, Labor and Stakeholder

Organizations

Atomic Trades and Labor

Council (ATLC)

Citizens Against Remediation

Extremes (CARE)

Citizens for Better Health

League of Women Voters

Nashville Peace Action-SANE/ FREEZE

Oak Ridge Environmental Peace Alliance (OREPA)
Oil, Chemical, \& Atomic Workers Union (OCAW)

Save Our Cumberland Mountains (SOCM)

Local Media Outlets

Wire Services

Associated Press

Knoxville, Tennessee

Newspapers

Clinton Courier Clinton, Tennessee

Clinch Valley Chronicle

Lake City, Tennessee

Dayton Herald -News

Dayton, Tennessee

Farragut Press Enterprise

Farragut, Tennessee

Harriman Record

Harriman, Tennessee

Jefferson County

Standard-Banner

Jefferson City, Tennessee

The Knoxville

News-Sentinel

Knoxville, Tennessee

Lenoir City News-Herald

Lenoir City, Tennessee 
Metro Pulse

Knoxville, Tennessee

The Oak Ridger

Oak Ridge, Tennessee

Rhea County Reporter

Dayton, Tennessee

Morgan County

Wartburg, Tennessee

Roane County News

Kingston, Tennessee

Rockwood Times

Rockwood, Tennessee

Scott County News

Oneida, Tennessee

The Standard

Kingston, Tennessee

Union News Leader

Maynardville, Tennessee

UT Daily Beacon

University of Tennessee,

Knoxville

Watts Bar Lake Observer

Spring City, Tennessee

Radio Stations

WIVK-FM\&AM

Knoxville, Tennessee
WOKI-FM

Knoxville, Tennessee

WMYU-FM

Knoxville, Tennessee

WLOD-AM

Loudon, Tennessee

WBLC-AM

Lenoir City, Tennessee

WUTK-FM

Knoxville, Tennessee

WYSH-AM

Clinton, Tennessee

WEZK-FM

Knoxville, Tennessee

WXVO-FM

Clinton, Tennessee

WNOX-AM

Jefferson City, Tennessee

WLIL-AM and FM

Lenoir City, Tennessee

WATO-AM

Oak Ridge, Tennessee

WIMZ-FM

Knoxville, Tennessee

WOFE Radio

Rockwood, Tennessee
WRGZ-FM

Harriman, Tennessee

WWBR-AM

Harriman, Tennessee

Television Stations

Oak Ridge Community Television, Channel 12

Oak Ridge, Tennessee

WATE-TV, Channel 6 Knoxville, Tennessee

WBIR-TV, Channel 10

Knoxville, Tennessee

WKCH-TV, Channel 43

Knoxville, Tennessee

WKXT-TV, Channel 8

Knoxville, Tennessee 
DOE/OR/01-1445\&D2

\section{DISTRIBUTION}

1. L. V. Asplund

2. M. F. P. Delozier

3. D. M. Matteo

4. T. W. Morris

5-6. M. E. Musolf

7-8. P. T. Owen

9. A. S. Quist

10. D. C. White

11. Central Research Library

12. ER Document Management Center-RC

13. R. L. Nace, Team Leader, Fernald/Ohio Team, Office of Environmental Restoration, U.S. Department of Energy, Cloverleaf Building, EM-425, 19901 Germantown Road, Germantown $\mathrm{MD}, 20874$

14-15. R. C. Sleeman, Director, Environmental Restoration Division, DOE Oak Ridge Operations Office, P.O. Box 2001, Oak Ridge, TN 37831-8541

16. J. W. Wagner II, Team Leader, Portsmouth/Paducah/Weldon Spring Team, Office of Environmental Restoration, U.S. Department of Energy, Cloverleaf Building, EM-424, 19901 Germantown Road, Germantown, MD 20874

17-18. T. Teague, Science Applications International Corporation, 301 Laboratory Road, Oak Ridge, TN 37831 